\title{
Eefects Of Occupational Strain Among Police Officers To The General Security of A Community: A Case Of Murang'a Town, Murang'a County, Kenya.
}

\author{
Felix Kimotho \\ Wokabi Mwangi \\ John Omboto
}

\begin{abstract}
Strain at work in any profession negatively affects the people working and overall performance of employees. This in turn has a negative impact on production or quality of services being offered. This applies to police officers especially those working in major towns in Kenya where crime rate is too high and cost of living is unimaginably high. According to GOK crime report of 2014, Murang'a town being one of the Kenyan major towns has been rated as having highest crime levels culminated by illegal groupings like Mungiki and Gaza boys. Among the major crimes recorded in Murang'a include violent robberies, theft of motor vehicles, house breakings and burglary, kidnapping, bank robberies, homicides and gender violence among others. Reasons behind high crime rate in Murang'a town have not been clearly established so far. Many scholars have tried to establish causes of crime in Murang'a town and among the listed causes include poverty levels, population growth and proximity to Kenyan capital Nairobi among others but none has considered effects of occupational strain among police officers in the course of performance of their duties. Occupational strain among police officers could be having adverse effects on performance by police officers and in turn negatively affect services they render to the public and this may lead to high crime rate and general insecurity. Failure to address causes of occupational strain among police undermines effort to curb insecurity in our major towns in Kenya. Strained officers are poorly motivated and generally demoralized hence poor service delivery. The focus of this paper, therefore, is to build greater understanding of the causes of occupational strain among police officers in Murang'a town, effects of such strain to general security of Murang'a town and possible measures that can be undertaken to address the problem of occupational strain among police officers working in Murang'a town. The paper briefly presents findings of research conducted in Murang'a town over the same topic and recommendations thereto, in order to address the problem of occupational strain among police officers and improve their welfare and wellbeing. All this is aimed at motivating them to provide good services and to make them more effective which in turn will improve security of Murang'a town.
\end{abstract}

Key words: Strain- challenges, difficulties, obstacles or undesirable feeling either physical or psychological. Security Management- identification of community's overall assets and risks followed by the development, documentation, and implementation of policies and procedures to protect the community and it assets and the strategic application of resources to monitor, minimise and control the probability or impact of identified risk. Insecurity- feeling of uncertainty and lack of confidence or assurance. Occupational Strain- physical or psychological problems, challenges or undesirable feeling associated with an occupation that hinders performance. Strain Management Efforts- wide spectrum of techniques and psychotherapies aimed at controlling a person's level of strain for the purposes of improving everyday functioning. Causesoverall predisposing conditions that brings about, generate, prompt, induce, promote or trigger emergence of strain. Effects- positive or negative results, consequences, 
repercussions or impacts emanating from strain. Stress- physical, physiological, or psychological disorder associated with occupational strain.

\section{INTRODUCTION}

This paper examines the effects of occupational strain among police officers working in Murang'a town and the effects of such strain to general security of Murang'a town. The paper also explores major causes of occupational strain among police officers in Murang'a town and suggests possible solutions to the problem. It is motivated by the concerns by the high level of insecurity recorded in Murang'a town culminated by illegal groups still operating within the town despite efforts by security agencies to curb the menace. While the Government is managing to subdue these violent groups of criminals in Kenya towns like wakali wale and sungusungu in Mombosa, Kamjesh in Kisumu and Kayole boys in Nairobi, their activities within Murang'a town still persists unperturbed. Security agencies in Murang'a seem to be overwhelmed leaving these criminals to thrive at the expense of security of the citizens living in Murang'a town and its environs. These groups operate in areas of Mukuyu and Mujini in Muarng'a and rob people as early as $6.30 \mathrm{pm}$ in the evening. Membership of these groups comprise of young boys who have dropped out of school aged between thirteen to twenty five years but are commonly coordinated by a more older persons who are more experienced in crime. They are known to carry knives and threaten people walking within those areas. Many cases of violent robberies, rape and defilements, homicides and many more have been reported recently. These groups' activities are spreading fast to other parts of town leaving everybody in Murang'a generally insecure. Many victims of these criminal gangs do no report after attack even if they were able to identify the criminals due to fear of further victimization.

Despite deployment and constant patrols by police, no positive results are achieved. Their strategies and action to curb this problem are seemingly not working. Reasons has to why the security agencies are unable to tackle the issue are not know. Probably police are working hand in hand with these criminals though this has not been confirmed. This therefore leads to the question of motivation by agencies to end the menace and neutralize the gangs. Police are strained and demoralized due to many factors that are highlighted in this paper to the extent of being unable to handle this situation. Among the factors mentioned in this paper include poor handling of police welfare, poor salaries, lack of proper equipments, and lack of support by seniors and political interference. This paper has also noted that number of police officers deployed in Murang'a town is low as compared to recommended numbers. This leads to long working hours to cover the shortage further straining the officers. The research that was conducted on the same topic indicate that a police officer in Murang'a works for at least twelve hours per day and have no weekend off duty. The issue of occupational strain among police officers therefore takes the centre role in escalating crime rates in Murang'a town. It also immensely contributes to rising cases of corruption to compensate for low salaries. It also contributes to emerging case of police brutality which could probably be a reaction to fatigue, stress, stress and feeling of hopelessness. In Murang'a, cases of suicide by police officers, and shooting of police seniors have been witnessed which could as well be as a result of stress emanating from occupational strain. Measures to curb this situation have been proposed in this paper which include management of police welfare and allocation of enough resources to police.

\section{PROBLEM ANALYSIS}

Occupational strain among police officers in Kenya has escalated despite many measures being put in place to curb the situation. Strain among police officers who provide security services may lead to occupational stress and adversely affect security management. In the recent past there have been many cases of police officers turning their guns on themselves, their colleagues or their superiors and others shooting their spouses and their children dead. In all these ugly incidents involving the police, there has been no proper explanation or reason for it. 
Many police officers especially in Murang'a town are also in record for absconding duty, desertion, low motivation, addiction to drugs and alcohol, resignation seeking green pastures and others engaging in crime, corruptions, violations of human rights and general impunity. All these are manifestations of occupational stress which probably emanate from occupational strain. Murang'a town has been in record for a long time for having highest crime levels which reason has not been properly established. Research conducted in Murang'a town indicated that police officers working there are labouring under serious occupational strain which could be hindering their performance of duty leading to high crime levels. It was therefore necessary to highlight this situation in this paper in order to build greater understanding of the causes of occupational strain among police officers in Murang'a town, effects of such strain to general security of Murang'a town and possible measures that can be undertaken to address the problem of occupational strain among police officers working in Murang'a town.

\section{METHODOLOGY}

This paper is informed by a study that was conducted in Murang'a town which was intended to establish major causes of occupational strain among police officers in Kenya and the effects it has on security management. The study sort to examine the major causes of occupational strain among police officers in Murang'a town, explore the effects it has on security management and assess the efforts being made by relevant authorities and organizations to manage strain. The study focused on police officers attached to Murang'a town. It employed social strain theory by Robert K Merton and Robert Agnew and general systems theory by Ludwig von Bertalanffy. Cross-sectional research design was used during the study and the target population of the study comprised of 120 police officers drawn from both Administration Police and Regular Police attached to Murang'a. The sample size was 60 respondents comprising of 40 respondents selected randomly from the two groups of the police which will be $33 \%$ of the entire population and 20 key informants drawn from businessmen in Murang'a town, experts, administrators, and senior police officers. Stratified sampling was used to select the respondents. Primary data was collected through in depth interviews using interview schedules and focus group discussions. This was corroborated with secondary data which was obtained from police records, archive documents, books and other written materials. Data collected was analyzed using SPSS (Statistical Package for Social Sciences). Descriptive statistics was used to interpret the data and inferential statistics to draw conclusions.

\section{RESULTS AND DISCUSSIONS}

The findings of this study revealed that most police officers find their job stressful. In addition, most police officers are not satisfied with their job hence if they got an opportunity they would not hesitate to change. The findings have also shown that most police officers work for long hours which could be straining them. The findings confirm Ostermann's (1999) assertion that strain is often related directly to the work situation. Most police officers are dissatisfied with their salaries and do not consider it proportionate to their labor.

The study revealed that most police officers consider their profession dangerous. They put their life on the line as they carry out their duty. The findings have shown that there is poor cover for police officers when injured in line of duty. These findings confirm that as Jones et al. (1995) observed, organizational demands are possible cause of strain at work. While there are some observed, organizational demands are possible cause of strain at work. While there are some senior police officers who are supportive to their juniors, many others are not supportive which make the work of their juniors hard and straining. The findings are in agreement with observations by Hart et al, (1995) that hostile work cultures that are characterized by mistrust, poor communication and lack of control can be a source of strain. 
Most police officers do not have adequate apparatus or tools to do their work properly. This not only has the potential to expose them to danger but also make their work straining. The findings have also shown that while most promotions in the National Police Service are largely fair, there could be significant incidents of unfairness. Disciplinary cases in the National Police Service are largely handled fairly with only a few cases of unfairness. The study has revealed mixed reactions in regard to involvement of police officers in decision making. While most police officers are involved in decision making a significant proportion are not included in decision making and therefore feel that their opinions do not matter.

The findings have shown that most police officers are regularly transferred from one work station to another which affects them and their families. This can be a source of strain as demonstrated by Parker (1998) who argued that harassment at work and a heightened sense of anxiety can be a source of strain that eventually affects performance. The study revealed a poor relationship between the police officers and the media. The results further demonstrated a breakdown of relations between the community, civil society and police officers. Working in such an environment can be a source of strain for police officers. The findings confirm observations by Hart et al. (1995) that hostile work environment, mistrust and poor communication can be a source of strain at workplace.

According to the findings of this study, current laws and regulations do not give police officers a good environment to work in and this could make them strain in their work. The study has shown that most police officers view IPOA unfavorably. The long working hours, risky nature of police work, and frequency of transfers make police job stressful and this can explain why many police officers would wish to change their profession. The situation is exacerbated by salaries that are not commensurate to work that police officers do, perceived unfairness of IPOA by the police officers, lack of media support as well as lack of support from the public and civil society and lack of proper cover when police officers are injured in the line of duty. Issues touching on resource allocation and welfare of police officers largely lead to occupational strain among police officers. These findings are contrary to observations by Ganster and Schaubroeck (1991) that personal characteristics are the major factors that lead to occupational strain.

The findings have shown that strain related illnesses are common among police officers. A high proportion of police officers drink alcohol, smoke or abuse substances which perhaps could be due to strain emanating from their work. The findings confirm observations by Jex (1998) who pointed out that occupational strain and stressful working conditions can lead to behavioural stress, physical stress and psychological stress. The study revealed a high prevalence of homicides among police officers which perhaps could be linked to stressful work.

Although a small number of police officers resigned, deserted or absented themselves from duty when looked at from employee turnover perspective, this is a high rate that should raise concerns about police officers' welfare. If left unattended strain among the police officers can eventually significantly affect police work and productivity. The findings confirmed that unless there is adequate intervention to resolve the problem of strain among police officers, the security sector will be affected. Security services delivery will diminish and insecurity will increase. Strain at work is a factor that affects performance of security services at both management level and community level.

The findings have shown that additional efforts to curb strain among police officers are necessary. In addition, there is need for more proactive strategies to curb strain among police 
officers as well as a review of the existing strategies to make them work. As Lazarus and Folkman (1984) pointed out intervention can reduce the risk of health associated with strain in the workplace. The study has revealed that the issue of managing strain among the police officers have largely been left to the government with only a few other organizations assisting to address the problem.

The contribution of a few other organizations in management of strain among police officers has not done much to address the problem. This is contrary to individual and organizational approaches for intervention proposed by Lazarus and Folkman (1984). There are strategies that have not been explored that could have significant impact on curbing strain among police officers. These include primary, secondary and tertiary as advocated by Worker Compensation and Rehabilitation Commission (2000). The findings revealed that there are no tangible strategies for curbing strain among police officers. Despite there being police officers who are already adversely affected by strain at work, there are no tangible strategies such as case management advocated by Ganster (1995) for such situations.

\section{Introduction}

\section{CONCLUSIONS AND RECOMMENDATIONS}

This is the summary of findings, conclusions and recommendations of the study.

\section{Summary}

The findings revealed that police officers find their job stressful and most police officers were not satisfied with their job. If most police officers got an opportunity they would not hesitate to change their profession. The cause of strain at work emanates from long working hours, salaries that are not proportionate to police officers' work and the dangerous nature of police work. The findings also show poor cover for police officers when injured in line of duty and lack of support from some senior police officers make the work of their juniors straining. The police officers do not have adequate apparatus or tools to do their work properly hence endangering the officers and causing them strain.

The findings revealed that while most promotions in the National Police Service are largely fair, there could be significant incidents of unfairness. Similarly, disciplinary cases in the National Police Service were largely handled fairly with only a few cases of unfairness. The findings have shown that while most police officers are involved in decision making a significant proportion are excluded in decision making and their opinions do not matter. The findings revealed regular transfers from one work station to another among police officers. The results revealed a poor relationship between the police officers and the media as well as the community and the civil society. The results have shown that current laws and regulations do not give police officers a good environment to work and police officers perceive IPOA as not fair to them.

The findings shows that strain related illnesses are common among police officers. The results also show that a high proportion of police officers drinking alcohol, smoking or abusing substances which perhaps could be due to strain emanating from their work. There is also a high prevalence of homicides among police officers which perhaps could be linked to stressful work. This has led to increased employee turnover among police officers as some resigned, deserted or absented themselves from duty. The results have shown that if left unattended strain among the police officers can eventually affect police work and productivity. The findings show need for intervention to resolve the problem of strain among police officers so that security services delivery is not interrupted. 
The findings show need for additional efforts to curb strain among police officers but the issue have largely been left to the government with only a few other organizations assisting to address the problem. The contributions of the few other organizations that assist in management of strain among police officers have not done much to address the problem. The findings have shown that there are unexplored strategies that could have significant impact on curbing strain among police officers.

\section{Conclusion}

Many sources of strain among police officers are job related. Long working hours, risky nature of police work, and frequency of transfers make police job stressful and this can explain why many police officers would change their profession if they got a chance to do so. The situation has been exacerbated by salary that is not commensurate to work that police officers do, perceived unfairness of IPOA against police officers, lack of media support as well as lack of support from public and civil society and lack of proper cover when police officers get injured in the line of duty. Issues touching on resource allocation and welfare of police officers seem to largely contribute to occupational strain among police officers.

The effects of occupational strain among police officers are manifested in many aspects such as stress related illnesses, a high proportion of police officers drinking alcohol, smoking or abusing substances and a high prevalence of homicides. These incidents raise concerns about police officers' welfare. They show that unless there is adequate intervention to resolve the problem of strain among police officers, the security sector will be affected. Security services delivery could diminish creating a room for insecurity to increase. Based on the findings of this study, strain at work is seen as a critical factor that affect performance of security services at both management level and community level.

Proactive strategies to curb strain among police officers are needed. The government alone cannot adequately address the problem of strain among police officers hence need for assistant from other organizations and stakeholders in security sector. The unexplored strategies for curbing strain among police officers could have positive impact and there is need to explore and exploit available means to establish tangibles strategies to curb strain among police officers.

\section{Recommendations}

The study recommended that the government, National Police Service Commission and other stakeholders in the security sector should address concerns relating to police officers' welfare and resource allocation to mitigate strain among police officers. The sources of strain that are job related such as long working hours, nature of work and transfers could be addressed by the National Police Service Commission. Addressing other sources of strain among police officers, such as resource allocation for better remuneration, adequate equipment to work with and support need collaboration among stakeholders such as NPSC, government, the media civil society and the community. These organizations should work together to assist the police officers deal with occupational strain.

The study recommended that NPSC should work with counseling psychologists and other stakeholders to address strain related illnesses, alcoholism, substance abuse and a high prevalence of homicides. These illnesses have not only affected police officers' performance and productivity but also their general welfare and that of their families. This shows the need for immediate remedial efforts as long term strategies are put in place. 
The study recommended that the NPSC should be proactive in developing and reviewing strategies to not only address strain among police officers but also welfare of the police officers. NPSC should allocate resources for research on how well to motivate police officers in their work despite the challenges that come with the nature of their job. Such efforts should be comprehensive covering social, political, economic and environmental conditions that affect police officers work.

\section{References}

Agnew, R. (1992), Foundation for a General Strain Theory of Crime and Delinquency. Criminology. 30(1), 47-87.

Baruch, Y \& Hind, P. (1999). Perpetual Motion in Organizations: Effective Management and the Impact of the New Psychological Contracts on Survivor Syndrome. 8 (2):295-306.

Colligan, T. Et Al (2006). Workplace Strain- Etiology and Consequences: Journal of Work Place Behavioral Health 21 (2):89-97

Conway, V.J. \& Terry, D.J. (1992). Appraised Controllability as a Moderator of the Effectiveness of Different Coping Strategies: A Test of the Goodness of Fit Hypothesis. Australian Journal of Psychology, 44:1-7.

Gangster, D.(1995) Interventions for Building Healthy Organizations: Suggestions from the Strain Research Literature.' American Psychological Association, Washington DC

Ganster, D.C. and Schaubroeck, J. (1991). Work Strain and Employee Health. Journal of Management, 17: 235-271

Hart, P., \& Wearing, A. (1995). Occupational Strain and Well-Being: A Systematic Approach to Research, Policy and Practice. In. C. Cotton (Ed). Psychological Health in the Workplace: Understanding and Managing Occupational Strain (Pp. 185-216). Melbourne: Australian Psychological Society.

Hoffmann, J and Alan, M. (1998), A Latent Variable Analysis of General Strain Theory.

Janis, L And Leventhal, H. (1968), Human Reaction to Strain, R and Mcnally, Chicago

Jex, S.M. (1998), Strain and Job Performance Theory, Research and Implications for Managerial Practice, Thousand Oaks C.A Sage

Jones, S. (2008), Criminology, Fourth Edition. Oxford University Press, Newyork.

Jones, B. Flynn, D. and Kelloway, E. (1995). Perception of Support from the Organization in Relation to Work Strain, Satisfaction, and Commitment. In S. Sauter \& L.

Lazarus, M. (1991), Psychological Strain in The Work Place, Select Press, Corte Madeira

Lazarus, R and Folkman, S. (1984).Strain and Coping, Springer. Newyork

National Institution for Occupational Safety and Health NIOSH (1999) U S, Strain at Work, DHHS (NIOSH)

Publication Number 99-101

Orodho, A.J. (2003), Essential of Educational and Social Science Research Methods. Masola publishers, Nairobi.

Ostermann, R.F. (1999). The SWS Strain / Support Mode.NJ: School Of Psychology: Fairleigh Dickinson University.

Parker, S.K., Griffith, M.A., \& Holdaway, S. (1999). What is so Distraining About a Little Name Calling and Teasing? Work Performance Anxiety as an Explanation of the Negative Effects of Harassment. In Proceedings of Work Strain and Health, 99: Organization of Work in A Global Economy. Baltimore: National Institute for Occupational Safety and Health.

Princeton Survey Research Association (1997), Labor Day Survey; State of Workers, Princeton, NJ: Princeton Survey Research Association

Elizabeth, K. Et Al, (2000), Occupation Stress: Factors that Contribute to its Occurrence and Effective Management. A Report to the Workers' Compensation \& Rehabilitation Commission, Centre for Human Services, Griffith University, Western Australia.

Rukwaru, M. (2008), Anatomy of Crime, Eureka Publishers, Nairobi.

Tannenbaum, F. (1938), Crime and the Community, Colombia University Press, New York

The Kenya Police Service Annual Crime Report 2014, GOK (2014), Government Press, Nairobi 